\title{
Unravelling moral cognition in acquired brain injury: a scoping review
}

\author{
Beth Lloyd $^{1,2 *}$ (i), Estrella R. Montoya ${ }^{1}$, Lycia D. de $\operatorname{Voogd}^{3}$ and Erik Oudman ${ }^{1,4}$ (D) \\ ${ }^{1}$ Utrecht University, Department of Experimental Psychology, Helmholtz Institute, Utrecht, The Netherlands, ${ }^{2}$ Department of \\ Psychology, Leiden University, Leiden, The Netherlands, ${ }^{3}$ Donders Institute for Brain, Cognition and Behaviour, Radboud \\ University Nijmegen, Nijmegen, The Netherlands and ${ }^{4}$ Slingedael Korsakoff Center, Rotterdam, The Netherlands \\ *Corresponding author. Email: b.lloyd@fsw.leidenuniv.nl
}

(Received 17 June 2020; revised 02 February 2021; accepted 06 February 2021)

\begin{abstract}
Background: Acquired brain injury (ABI) is accompanied by impairments in social, emotional, cognitive and behavioural skills and highly prevalent in the population. Social and emotional skills are crucial for moral cognition, but the extent to which moral cognition contributes to social competence deficits in people with $\mathrm{ABI}$ is largely unclear.

Method: To provide more insight on this topic, we conducted a scoping review according to the PRISMA guidelines. After screening 1269 articles that we obtained via PubMed and Scopus, we found 27 articles on moral cognition in ABI.

Results: We encountered four important topics across these studies which include traumatic brain injury (TBI) versus non-TBI, the influence of the different approaches used to measure moral cognition in ABI, the role of age of onset and the role of location of the injury. Overall, evidence suggests that the earlier the brain damage occurred, the more this leads to impairments in moral cognitive functioning. The location of the injury furthermore seems to differentially affect the way impairments are manifested. Finally, we found that the use of different measurement approaches can heavily influence the interpretation of the impairment. Conclusion: We conclude that impairments in moral cognition in people with ABI are derived from a complex interplay between the age of onset, the location and the approach used to index moral cognition.
\end{abstract}

Keywords: acquired brain injury; traumatic brain injury; ventromedial prefrontal cortex; moral reasoning; scoping review

\section{Introduction}

People suffering from acquired brain injury (ABI), defined by any brain damage occurring after birth, often present large deficits in social competence (Anderson et al., 2017; Lalonde, Bernier, Beaudoin, Gravel \& Beauchamp, 2018; Sirois et al., 2017). Indeed, people with ABI have impairments in the social, emotional, cognitive and behavioural skills that are needed for successful social adaptation and interactions. Such deficits can place a great emotional burden on the individual and their social surroundings. An important aspect that may contribute to social competence is moral cognition (Palmer \& Hollin, 1999). Morality includes the sets of customs and values that are taken up by a cultural group to guide social conduct (Moll, Zahn, de Oliveira-Souza, Krueger \& Grafman, 2005). In this review, moral cognition will be used as an umbrella term referring to moral judgement, moral decision-making or moral reasoning. Interestingly, there is a high prevalence rate of brain injury in young offenders (Schofield, Mason, Nelson, Kenny \& Butler, 2019), and a meta-analysis of 50 studies found a strong association between developmentally delayed moral judgement and juvenile delinquency (Stams et al., 2006), suggesting an association between $\mathrm{ABI}$ and impaired moral cognition. However, the extent to which moral cognition 
contributes to social competence deficits in people with ABI is largely unclear (Beauchamp, Dooley \& Anderson, 2013; Beauchamp, Vera-Estay, Morasse, Anderson \& Dooley, 2019; Turkstra, Norman, Mutlu \& Duff, 2018).

For decades, scientists have tried to understand the neural basis of moral cognition by assessing how healthy individuals respond to scenarios in which there is a social problem. Functional neuroimaging studies have located a number of brain regions that were consistently active during tasks assessing human moral cognition, including regions in the frontal lobes, temporal lobes and subcortical structures (Young \& Dungan, 2012). Emotional processing often lies at the heart of these moral scenarios, where, for example, the choice of action may be to lie, cheat, steal or harm. People with ABI may therefore respond differently to these moral scenarios than healthy individuals due to their deficits in socio-emotional competence. Reports on understanding socioemotional deficits have turned to investigate the contribution of social cognition, referring to functions such as theory of mind (i.e., the ability to attribute mental states to others), empathy (i.e., the ability to understand the feeling of another) and emotion recognition (i.e., the ability to recognize emotions of others; Beauchamp et al., 2013, 2019; Cicerone \& Tanenbaum, 1997; Turkstra et al., 2018). The extent of the problems arising from these socio-emotional deficits is largely unknown, and the concepts to investigate the social aspect of ABI are a relatively new field of research. Critically, little research has sought to understand the contribution of these socio-emotional deficits in ABI to moral cognition, and it is unclear whether moral cognition is consistently hampered in ABI. This scoping review, carried out according to the PRISMA extension guidelines for a scoping review (PRISMA-ScR; Tricco et al., 2018), therefore, integrates the available evidence on moral cognition in ABI with the aim to create an overview of the findings (summary of literature in Table 1). We end this review by proposing meaningful directions for future research, in order to establish more coherent ways of studying moral cognition in ABI.

\section{Methods}

For our review approach, we applied the scoping review framework outlined by Colquhoun et al. (2014), with additional work from Arksey and O’Malley (2005) and Levac et al. (2010). According to this framework, we carried out the following procedures: (1) identifying the question; (2) identifying relevant studies; (3) selecting appropriate studies (4) charting the data; and (5) collating, summarising and reporting results.

\section{(1) Identifying the research question}

We initially formulated the research question 'What does the existing literature present about moral decision-making in people with acquired brain injury?'. Upon gathering the literature, it was apparent that this question did not adequately cover the scope of the moral literature in people with ABI, since many early studies focussed on moral reasoning rather than moral decisionmaking. This led us to generate a broader research question covering multiple aspects of moral thinking, thus, the following revised research question was formulated: 'What does the existing literature present about moral cognition in people with acquired brain injuries?'

\section{(2) Identifying relevant studies}

A systematic literature search was carried out using the PRISMA checklist (Tricco et al., 2018). Literature searches were carried out in September 2020 for studies published over the last 30 years. Three steps were carried out in order to identify relevant studies.

First, a literature search was carried out in search engines: PubMed and Scopus (see Table 2). The search terms include brain regions identified as regions known to be involved in human moral cognition (Moll et al., 2005) and multiple terms were used for brain injury, also terms that refer to common aetiologies of ABIs to ensure no relevant articles were missed. 
Table 1. Characteristics of studies assessing moral behaviour in acquired brain injury

\begin{tabular}{|c|c|c|c|c|c|c|c|}
\hline Authors & Sample & Age of onset ${ }^{a}$ & Age of testing & Location & $\begin{array}{l}\text { Moral behavioural } \\
\text { measures }\end{array}$ & $\begin{array}{l}\text { Task } \\
\text { mode }\end{array}$ & Study outcomes ${ }^{b}$ \\
\hline $\begin{array}{l}\text { Price et al., } \\
1990\end{array}$ & $\begin{array}{l}\text { TBI }(n=1), \text { non-TBI } \\
\quad(n=1)\end{array}$ & 7 days and 4 years & $\begin{array}{l}31 \text { years and } \\
26 \text { years }\end{array}$ & $\begin{array}{l}\text { Bilateral } \\
\text { frontal lobe }\end{array}$ & $\begin{array}{l}\text { Standard Issue Moral Judgement } \\
\text { (Colby \& Kohlberg, 1987) }\end{array}$ & $\mathrm{N} / \mathrm{A}$ & $\begin{array}{l}\text { Early conventional stage } \\
\text { and preconventional } \\
\text { stage of Kohlberg's } \\
\text { Model (1969) }\end{array}$ \\
\hline $\begin{array}{l}\text { Saver \& } \\
\text { Damasio, } \\
1991\end{array}$ & Non-TBI $(n=1)$ & 35 years & 40 years & vmPFC & $\begin{array}{l}\text { Standard Issue Moral Judgement } \\
\text { (Colby \& Kohlberg, 1987) }\end{array}$ & interview & $\begin{array}{l}\text { Late conventional/early } \\
\text { postconventional stage } \\
\text { of Kohlberg's Model } \\
\text { (1969) }\end{array}$ \\
\hline $\begin{array}{l}\text { Grattan \& } \\
\quad \text { Eslinger, } \\
1992\end{array}$ & Non-TBI $(n=1)$ & 7 years & 33 years & $\begin{array}{l}\text { Left Frontal } \\
\text { lobe }\end{array}$ & $\begin{array}{l}\text { Standard Issue Moral Judgement } \\
\text { (Colby \& Kohlberg, 1987) }\end{array}$ & interview & $\begin{array}{l}\text { Preconventional stage of } \\
\text { Kohlberg's Model } \\
\text { (1969) }\end{array}$ \\
\hline $\begin{array}{l}\text { Anderson } \\
\quad \text { et al., } 1999\end{array}$ & $\begin{array}{l}\mathrm{TBI}(n=1), \text { non-TBI } \\
\quad(n=7)\end{array}$ & $\begin{array}{l}\text { Early-onset: } 15 \\
\text { months and } \\
3 \text { months, adult- } \\
\text { onset: } 26-51 \text { years }\end{array}$ & $\begin{array}{l}\text { Early-onset: } \\
20 \text { years and } \\
23 \text { years, adult- } \\
\text { onset: } \\
\geq 27 \text { years }\end{array}$ & $\begin{array}{l}\text { Prefrontal } \\
\text { cortex }\end{array}$ & $\begin{array}{l}\text { Standard Issue Moral Judgement } \\
\text { (Colby \& Kohlberg, 1987) }\end{array}$ & interview & $\begin{array}{l}\text { Preconventional stage of } \\
\text { Kohlberg's Model } \\
\text { (1969) }\end{array}$ \\
\hline $\begin{array}{l}\text { Couper et al., } \\
2002\end{array}$ & $\begin{array}{l}\text { ABI }(n=16) \text {, healthy } \\
\text { controls }(n=12)\end{array}$ & $\leq 13$ years & $8-16$ years & Frontal lobe & $\begin{array}{l}\text { Sociomoral Reflection Measure - } \\
\text { Short-form Gibbs et al. (1992) }\end{array}$ & interview & $\begin{array}{l}\text { Lower levels of moral } \\
\text { maturity }\end{array}$ \\
\hline $\begin{array}{l}\text { Ciaramelli } \\
\text { et al., } 2007\end{array}$ & $\begin{array}{l}\text { Non-TBI }(n=7) \text {, } \\
\text { healthy controls ( } n \\
=12 \text { ) }\end{array}$ & 43.1-63.3 years & $46-66$ years & VmPFC & $\begin{array}{l}\text { Personal, impersonal and non-moral } \\
\text { dilemma questionnaire ( } 45 \text { cho- } \\
\text { sen) (Greene et al., 2001) }\end{array}$ & $\begin{array}{c}\text { written } \\
\text { text }\end{array}$ & $\begin{array}{l}\text { Judge personal moral } \\
\text { violations as more } \\
\text { acceptable }\end{array}$ \\
\hline $\begin{array}{l}\text { Koenigs et al., } \\
2007\end{array}$ & $\begin{array}{l}\text { Non=TBI }(n=6), \\
\text { brain-damaged } \\
\text { controls }(n=12), \\
\text { healthy controls ( } n \\
=12 \text { ) }\end{array}$ & $33-59$ years & 43-66 years & vmPFC & $\begin{array}{l}\text { Personal (high-conflict and low-con- } \\
\text { flict), impersonal and non-moral } \\
\text { dilemma questionnaire (Greene } \\
\text { et al., 2001) }\end{array}$ & $\begin{array}{l}\text { written } \\
\text { text } \\
\text { Koenigs } \\
\text { et al. } \\
(2007)\end{array}$ & $\begin{array}{l}\text { People with vmPFC } \\
\text { damage judge high- } \\
\text { conflict personal moral } \\
\text { violations as more } \\
\text { acceptable }\end{array}$ \\
\hline Authors & Sample & Age of onset ${ }^{a}$ & Age of testing & Location & $\begin{array}{l}\text { Moral behavioural } \\
\text { measures }\end{array}$ & Task mode & Finding ${ }^{b}$ \\
\hline $\begin{array}{l}\text { Moretto et al., } \\
2010\end{array}$ & $\begin{array}{l}\text { Non-TBI }(n=8) \text {, non- } \\
\text { frontal brain dam- } \\
\text { aged controls } \\
(n=7), \text { healthy } \\
\text { controls }(n=18)\end{array}$ & $\begin{array}{l}\text { On average } \\
5.1 \text { years prior } \\
\text { to testing }\end{array}$ & $\begin{array}{l}M=53.1 \text { years } \\
\quad(S D=10.8)\end{array}$ & vmPFC & $\begin{array}{l}\text { Personal (high-conflict and } \\
\text { low-conflict), impersonal } \\
\text { and non-moral dilemma } \\
\text { questionnaire ( } 45 \text { cho- } \\
\text { sen) (Greene et al., 2001) }\end{array}$ & written text & $\begin{array}{l}\text { Judge high-conflict } \\
\text { personal moral } \\
\text { violations as more } \\
\text { acceptable }\end{array}$ \\
\hline
\end{tabular}




\begin{tabular}{|c|c|c|c|c|c|c|c|}
\hline Authors & Sample & Age of onset ${ }^{a}$ & Age of testing & Location & $\begin{array}{l}\text { Moral behavioural } \\
\text { measures }\end{array}$ & Task mode & Finding ${ }^{b}$ \\
\hline $\begin{array}{l}\text { Croft et al., } \\
2010\end{array}$ & $\begin{array}{l}\text { Non-TBI }(n=8) \text { and } \\
\text { brain-damaged } \\
\text { controls }(n=16)\end{array}$ & $\begin{array}{l}\text { Hippocampal } \\
\text { lesion: } 42-45 \\
\text { years, vmPFC } \\
\text { lesion: } \\
\text { 40-59 years, }\end{array}$ & $\begin{array}{l}\text { Hippocampal lesion: } \\
\text { 49-59 years, vmPFC } \\
\text { lesion: } 57-67 \text { years, }\end{array}$ & $\begin{array}{l}\text { Bilateral hippo- } \\
\text { campus }(n=4) \text {, } \\
\text { vmPFC }(n=4)\end{array}$ & $\begin{array}{l}\text { Moral updating task (Croft } \\
\text { et al., 2010) }\end{array}$ & $\begin{array}{l}\text { pictures/audio } \\
\text { description }\end{array}$ & $\begin{array}{l}\text { People with vmPFC } \\
\text { damage show } \\
\text { reduced moral } \\
\text { updating, People } \\
\text { with HC lesions } \\
\text { show exaggerated } \\
\text { moral updating }\end{array}$ \\
\hline $\begin{array}{l}\text { Young et al., } \\
2010\end{array}$ & $\begin{array}{l}\text { TBI }(n=1) \text { non-TBI } \\
(n=8) \text {, brain- } \\
\text { damaged controls } \\
(n=7) \text {, healthy } \\
\text { controls }(n=8)\end{array}$ & $33-59$ years & $46-73$ years & vmPFC & $\begin{array}{l}\text { Belief attribution and } \\
\text { moral judgement ( } 48 \\
\text { scenarios) (Young et al., } \\
2007 \text { ) }\end{array}$ & written text & $\begin{array}{l}\text { Judge attempted } \\
\text { harm as more } \\
\text { permissible and } \\
\text { accidental harm } \\
\text { less permissible }\end{array}$ \\
\hline $\begin{array}{l}\text { Dooley et al., } \\
2010\end{array}$ & $\begin{array}{l}\text { TBI }(n=25) \text {, healthy } \\
\text { controls }(n=26)\end{array}$ & $\mathrm{N} / \mathrm{A}$ & $\begin{array}{c}M=13.7 \text { years } \\
(S D=2.1)\end{array}$ & $\mathrm{N} / \mathrm{A}$ & $\begin{array}{l}\text { Socio-moral reasoning } \\
\text { task, socio-moral matu- } \\
\text { rity task (Dooley et al., } \\
2010 \text { ) }\end{array}$ & pictures & $\begin{array}{l}\text { No difference to } \\
\text { control group in } \\
\text { moral } \\
\text { maturity }\end{array}$ \\
\hline $\begin{array}{l}\text { Thomas et al., } \\
2011\end{array}$ & $\begin{array}{l}\text { Non-TBI }(n=9), \\
\text { brain-damaged } \\
\text { controls }(n=9)\end{array}$ & $33-63$ years & $45-68$ years & vmPFC & $\begin{array}{l}\text { High-conflict direct self and } \\
\text { indirect self-dilemmas } \\
\text { (17 chosen), other per- } \\
\text { sonal dilemmas (12 cho- } \\
\text { sen) (Greene et al., 2001) }\end{array}$ & written text & $\begin{array}{l}\text { Utilitarian bias in } \\
\text { high-conflict } \\
\text { personal moral } \\
\text { dilemmas }\end{array}$ \\
\hline $\begin{array}{l}\text { Ciaramelli } \\
\quad \text { et al., } 2012\end{array}$ & $\begin{array}{l}\text { TBI }(n=3) \text { non-TBI } \\
(n=11), \text { non-FC } \\
\text { TBI }(n=9), \text { healthy } \\
\text { controls }(n=20)\end{array}$ & $\begin{array}{l}\geq 6 \text { months prior } \\
\text { to testing }\end{array}$ & $\begin{array}{l}\text { Experiment } 1 \text { : } \\
M=54 \text { years } \\
\text { (SD }=13) \text {, Experiment } \\
\text { 2: } M=53 \text { years } \\
\text { (SD }=11) \text {, Experiment } \\
\text { 3: } M=54 \text { years } \\
(S D=13)\end{array}$ & vmPFC & $\begin{array}{l}\text { Belief attribution and } \\
\text { moral judgement ( } 48 \\
\text { scenarios) (Young et al., } \\
\text { 2007) }\end{array}$ & written text & $\begin{array}{l}\text { Judge attempted } \\
\text { harm as more } \\
\text { permissible and } \\
\text { accidental harm } \\
\text { less permissible }\end{array}$ \\
\hline $\begin{array}{l}\text { Martins et al., } \\
2012\end{array}$ & $\begin{array}{l}\text { TBI }(n=29), \text { healthy } \\
\text { controls }(n=41)\end{array}$ & $\begin{array}{l}\text { On average } \\
6.7 \text { years prior } \\
\text { to testing }\end{array}$ & $\begin{array}{l}\leq 40 \text { years }(M=29.3 \\
S D=5.9)\end{array}$ & $\begin{array}{c}\text { Frontal/temporal/ } \\
\text { occipital lobes }\end{array}$ & $\begin{array}{l}\text { Personal, impersonal and } \\
\text { non-moral dilemma } \\
\text { questionnaire ( } 22 \text { cho- } \\
\text { sen; Greene et al., 2001) }\end{array}$ & written text & $\begin{array}{l}\text { Utilitarian bias in } \\
\text { personal moral } \\
\text { dilemmas }\end{array}$ \\
\hline $\begin{array}{l}\text { Beauchamp } \\
\text { et al., } 2013\end{array}$ & $\begin{array}{l}\text { TBI }(n=25), \text { healthy } \\
\text { controls }(n=66)\end{array}$ & $11-19$ years & $M=14.3$ years $(S D=1.6)$ & $\mathrm{N} / \mathrm{A}$ & $\begin{array}{l}\text { Socio-moral reasoning } \\
\text { task, socio-moral matu- } \\
\text { rity task (Dooley et al., } \\
\text { 2010) }\end{array}$ & pictures & $\begin{array}{l}\text { Lower levels of moral } \\
\text { maturity }\end{array}$ \\
\hline
\end{tabular}


Table 1. (Continued)

\begin{tabular}{|c|c|c|c|c|c|c|c|}
\hline Authors & Sample & Age of onset ${ }^{a}$ & Age of testing & Location & $\begin{array}{l}\text { Moral behavioural } \\
\text { measures }\end{array}$ & Task mode & Finding ${ }^{b}$ \\
\hline $\begin{array}{l}\text { Cook et al., } \\
2013\end{array}$ & $\begin{array}{l}\text { TBI }(n=15), \text { healthy } \\
\text { controls }(n=13)\end{array}$ & $9.2-16.7$ years & $12.4-19.7$ years & $\mathrm{N} / \mathrm{A}$ & $\begin{array}{l}\text { Virtual anticipating } \\
\text { consequences task } \\
\text { (Hanten et al., 2011) }\end{array}$ & virtual-reality & $\begin{array}{l}\text { Stated less } \\
\text { long-term moral } \\
\text { consequences }\end{array}$ \\
\hline $\begin{array}{l}\text { Taber-Thomas } \\
\text { et al., } 2014\end{array}$ & $\begin{array}{l}\text { TBI }(n=3) \text { non-TBI } \\
(n=5) \text {, healthy } \\
\text { controls }(n=12), \\
\text { from Koenigs et al. } \\
(2007) \text { : non-TBI } \\
(n=6) \text {, brain- } \\
\text { damaged controls } \\
(n=9)\end{array}$ & $\begin{array}{l}\text { Early-onset: } \\
\text { 0-16.5 years, } \\
\text { adult-onset: } \\
\text { 33-59 years }\end{array}$ & $\begin{array}{l}\text { Early-onset: } \\
\text { 17.1-37.4 years, adult- } \\
\text { onset: } 43-66 \text { years }\end{array}$ & vmPFC & $\begin{array}{l}\text { Personal (high-conflict and } \\
\text { low-conflict), impersonal } \\
\text { and non-moral dilemma } \\
\text { questionnaire (Greene } \\
\text { et al., 2001) }\end{array}$ & written text & $\begin{array}{l}\text { People with early/ } \\
\text { adolescent } A B I \\
\text { endorse more } \\
\text { self-serving moral } \\
\text { dilemmas }\end{array}$ \\
\hline $\begin{array}{l}\text { Njomboro } \\
\text { et al., } 2014\end{array}$ & $\begin{array}{l}\text { TBI }(n=14) \text { non-TBI } \\
(n=35), \text { healthy } \\
\text { controls }(n=54)\end{array}$ & $\mathrm{N} / \mathrm{A}$ & $\begin{array}{c}M=48.7 \text { years } \\
(S D=11.8)\end{array}$ & $\begin{array}{l}\text { Parietal/fronto- } \\
\text { temporal lobes } \\
(n=46), \mathrm{N} / \mathrm{A} \\
(n=3)\end{array}$ & $\begin{array}{l}\text { Personal, impersonal and } \\
\text { non-moral dilemma } \\
\text { questionnaire ( } 30 \text { cho- } \\
\text { sen; Greene et al., 2001) }\end{array}$ & written text & $\begin{array}{l}\text { People with } \mathrm{ABI} \text { with } \\
\text { apathy endorse } \\
\text { more personal } \\
\text { moral dilemmas } \\
\text { than those without } \\
\text { apathy }\end{array}$ \\
\hline $\begin{array}{l}\text { Craver et al., } \\
2016\end{array}$ & $\begin{array}{r}\mathrm{TBI}(n=1) \text { non-TBI } \\
(n=11), \text { healthy } \\
\text { controls }(n=22)\end{array}$ & $22-59$ years & $44-62$ years & $\begin{array}{l}\text { Bilateral hippo- } \\
\text { campus }\end{array}$ & $\begin{array}{l}\text { Personal (high-conflict and } \\
\text { low-conflict), impersonal } \\
\text { and non-moral dilemma } \\
\text { questionnaire ( } 33 \\
\text { chosen; Greene et al., } \\
\text { 2001) }\end{array}$ & written text & $\begin{array}{l}\text { Judged moral dilem- } \\
\text { mas similarly to } \\
\text { healthy controls }\end{array}$ \\
\hline $\begin{array}{l}\text { McCormick } \\
\text { et al., 2016) }\end{array}$ & $\begin{array}{l}\text { Non-TBI }(n=5) \text {, } \\
\text { healthy controls } \\
(n=11)\end{array}$ & $18-61$ years & $27-70$ years & $\begin{array}{l}\text { Bilateral hippo- } \\
\text { campus }\end{array}$ & $\begin{array}{l}\text { Personal (high-conflict and } \\
\text { low-conflict), impersonal } \\
\text { and non-moral dilemma } \\
\text { questionnaire (Greene } \\
\text { et al., 2001) }\end{array}$ & written text & $\begin{array}{l}\text { Judged high-conflict } \\
\text { personal moral } \\
\text { violations as less } \\
\text { acceptable }\end{array}$ \\
\hline $\begin{array}{l}\text { Rowley et al., } \\
2018\end{array}$ & $\begin{array}{l}\text { TBI }(n=30) \text {, healthy } \\
\text { controls }(n=30)\end{array}$ & $\begin{array}{l}\geq 18 \text { years (on } \\
\text { average } \\
9.3 \text { years prior } \\
\text { to testing) }\end{array}$ & $\begin{array}{c}M=41.3 \text { years } \\
(S D=13.7)\end{array}$ & $\mathrm{N} / \mathrm{A}$ & $\begin{array}{l}\text { Moral dilemmas (10 utili- } \\
\text { tarian-intuitive, } 10 \\
\text { deontological-intuitive } \\
\text { selected) (Kahane et al., } \\
\text { 2012) }\end{array}$ & $\begin{array}{l}\text { story boards/car- } \\
\text { toons }\end{array}$ & $\begin{array}{l}\text { Counter-intuitive } \\
\text { preference } \\
\text { (Utilitarian bias in } \\
\text { extreme dilemmas, } \\
\text { deontological bias } \\
\text { in less extreme } \\
\text { dilemmas) }\end{array}$ \\
\hline
\end{tabular}


Table 1. (Continued)

\begin{tabular}{|c|c|c|c|c|c|c|c|}
\hline Authors & Sample & Age of onset ${ }^{\mathrm{a}}$ & Age of testing & Location & $\begin{array}{l}\text { Moral behavioural } \\
\text { measures }\end{array}$ & Task mode & Finding $^{\mathrm{b}}$ \\
\hline $\begin{array}{l}\text { Chiasson } \\
\text { et al., } 2017\end{array}$ & $\begin{array}{l}\text { Non-TBI }(n=15) \text {, } \\
\text { healthy controls } \\
(n=15)\end{array}$ & $2.3-13.0$ years & $8-16$ years & $\begin{array}{l}\text { Frontal/temporal } \\
\text { lobes }\end{array}$ & $\begin{array}{l}\text { Socio-moral reasoning task } \\
\text { (Dooley et al., 2010) }\end{array}$ & pictures & $\begin{array}{l}\text { Lower levels of } \\
\text { mature moral rea- } \\
\text { soning }\end{array}$ \\
\hline $\begin{array}{l}\text { Vascello et al., } \\
2018\end{array}$ & $\begin{array}{l}\text { TBI }(n=28) \text {, healthy } \\
\text { controls }(n=28)\end{array}$ & $15-59$ years & $21-63$ years & Widespread & $\begin{array}{l}\text { Moral and socio- } \\
\text { conventional task } \\
\text { (adapted from Turiel, } \\
\text { 1983) }\end{array}$ & audio description & $\begin{array}{l}\text { Moral items easier to } \\
\text { transgress than } \\
\text { social items }\end{array}$ \\
\hline $\begin{array}{l}\text { Cameron } \\
\text { et al., } 2018\end{array}$ & $\begin{array}{l}\text { Non-TBI }(n=8), \\
\text { brain-damaged } \\
\text { controls }(n=12), \\
\text { healthy controls } \\
(n=12)\end{array}$ & $\begin{array}{l}\geq 3 \text { months prior } \\
\text { to testing }\end{array}$ & $61-76$ years & vmPFC & $\begin{array}{l}\text { Moral categorisation task } \\
\text { (Cameron et al., 2018) }\end{array}$ & written text & $\begin{array}{l}\text { Weaker implicit } \\
\text { moral judgement }\end{array}$ \\
\hline $\begin{array}{l}\text { Ziaei et al., } \\
2019\end{array}$ & $\begin{array}{l}\mathrm{TBI}(n=3), \text { non-TBI } \\
(n=3) \text {, healthy } \\
\text { controls }(n=10)\end{array}$ & $\begin{array}{l}\geq 18 \text { years (on } \\
\text { average } \\
10.2 \text { years prior } \\
\text { to testing) }\end{array}$ & $32-64$ years & $\begin{array}{l}\text { Right Frontopolar } \\
\text { Cortex }\end{array}$ & $\begin{array}{l}\text { Personal, Impersonal moral } \\
\text { dilemma questionnaire } \\
\text { (12 chosen; Greene } \\
\text { et al., 2001) }\end{array}$ & audio description & $\begin{array}{l}\text { Normative responses } \\
\text { to personal and } \\
\text { impersonal moral } \\
\text { dilemmas, with } \\
\text { neutral, negative } \\
\text { and no emotion } \\
\text { induction }\end{array}$ \\
\hline $\begin{array}{l}\text { Beauchamp } \\
\text { et al., } 2019\end{array}$ & $\begin{array}{l}\text { TBI }(n=43), \text { healthy } \\
\text { controls }(n=93)\end{array}$ & $11-18$ years & $11-18$ years & $\mathrm{N} / \mathrm{A}$ & $\begin{array}{l}\text { Socio-moral reasoning } \\
\text { task, socio-moral matu- } \\
\text { rity task (Dooley et al., } \\
\text { 2010) }\end{array}$ & pictures & $\begin{array}{l}\text { Lower levels of moral } \\
\text { maturity }\end{array}$ \\
\hline $\begin{array}{l}\text { Asp et al., } \\
2019\end{array}$ & $\begin{array}{l}\text { TBI }(n=1), \text { non-TBI } \\
(n=9), \text { non-frontal } \\
\text { brain-damaged } \\
\text { controls TBI } \\
(n=16)\end{array}$ & $\begin{array}{l}\text { On average } \\
11.8 \text { years prior } \\
\text { to testing }\end{array}$ & $M=65.3$ years $(S D=7.3)$ & vmPFC & $\begin{array}{l}\text { Third-party punishment } \\
\text { task (Asp et al., 2019) } \\
\text { and moral judgment } \\
\text { vignette task }\end{array}$ & written text & $\begin{array}{l}\text { More lenient judge- } \\
\text { ment of violent } \\
\text { crimes, normative } \\
\text { judgement of non- } \\
\text { violent crimes }\end{array}$ \\
\hline
\end{tabular}

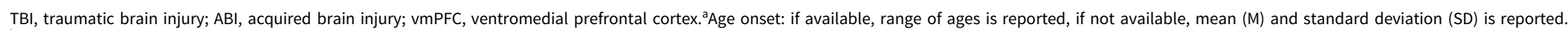
${ }^{b}$ Finding: summaries refer to people with ABI. 
Table 2. Search engines and search terms used for the current scoping review

\begin{tabular}{|c|c|}
\hline $\begin{array}{l}\text { Search } \\
\text { engine }\end{array}$ & Search terms \\
\hline PubMed & $\begin{array}{l}\text { (((((((((((((((()(((“brain injury“[Title/Abstract]) OR (“brain trauma“[Title/Abstract]])) OR (“brain } \\
\text { damage“[Title/Abstract])) OR ("head trauma“[Title/Abstract])) OR ("brain insult“[Title/Abstract])) } \\
\text { OR (stroke[Title/Abstract])) OR (TBI[Title/Abstract])) OR (“craniocerebral truama“[Title/Abstract])) } \\
\text { OR (lesion[Title/Abstract])) OR (vmpfc[Title/Abstract])) OR (vmpc[Title/Abstract])) OR } \\
\text { (ventromedial[Title/Abstract])) OR (orbitofrontal[Title/Abstract])) OR (dorsolateral[Title/Abstract])) } \\
\text { OR (hippocampus[Title/Abstract])) OR ("anterior cingulate“[Title/Abstract])) OR (precuneus[Title/ } \\
\text { Abstract])) OR (insula[Title/Abstract])) OR (amygdala[Title/Abstract])) OR (frontopolar[Title/ } \\
\text { Abstract])) AND (moral[Title/Abstract]) }\end{array}$ \\
\hline Scopus & $\begin{array}{l}\text { (TITLE-ABS-KEY (“brain injury”) OR TITLE-ABS-KEY (“brain trauma”) OR TITLE-ABS-KEY (“brain dam- } \\
\text { age”) OR TITLE-ABS-KEY (“head trauma”) OR TITLE-ABS-KEY (“brain insult”) OR TITLE-ABS-KEY } \\
\text { (stroke) OR TITLE-ABS-KEY (tbi) OR TITLE-ABS-KEY (“craniocerebral trauma”) OR TITLE-ABS-KEY } \\
\text { (lesion) OR TITLE-ABS-KEY (vmpfc) OR TITLE-ABS-KEY (vmpc) OR TITLE-ABS-KEY (ventromedial) OR } \\
\text { TITLE-ABS-KEY (orbitofrontal) OR TITLE-ABS-KEY (dorsolateral) OR TITLE-ABS-KEY (hippocampus) } \\
\text { OR TITLE-ABS-KEY (“anterior cingulate”) OR TITLE-ABS-KEY (precuneus) OR TITLE-ABS-KEY (insula) } \\
\text { OR TITLE-ABS-KEY (amygdala) OR TITLE-ABS-KEY (frontopolar) AND TITLE-ABS-KEY (moral)). }\end{array}$ \\
\hline
\end{tabular}

Second, the reference lists of relevant articles were checked for additional relevant articles. One relevant article was included through reference searches, since it was not available on the mentioned search engines.

Third, studies were excluded if (i) moral cognition was briefly mentioned and not directly measured under one of the following concepts: moral reasoning, moral maturity, moral decisionmaking, moral behaviour or moral actions; (ii) the sample were people with non-ABI, where the brain injury was caused in an event after birth. Injuries from the following aetiologies were not included: hereditary, congenital, degenerative or induced birth trauma; (iii) they were nonempirical studies, such as reviews or meta-analysis and (iv) they were written in a language other than English.

\section{(3) Study selection}

After duplicate removal, all titles and abstracts were reviewed to determine eligibility for this review as outlined in Fig. 1. The full article was reviewed if it remained unclear from reading the title and the abstract about whether the study met all of the relevant criteria for this review.

\section{(4) Charting the data}

Two authors extracted the following key elements from the studies in order to examine the research question: number of study participants, aetiology of ABI (traumatic brain injury (TBI), non-traumatic brain injury (non-TBI)), age of onset of $\mathrm{ABI}$, age at testing, location of $\mathrm{ABI}$, behavioural measures used to answer the research question, the mode of the task (i.e., how moral dilemmas were presented to people) and the main study outcomes (i.e., moral decisions of people with ABI compared to control groups). The following main study outcomes were extracted: preferences, behaviours and choices on behavioural tasks.

\section{(5) Collating, summarising and reporting the results}

In order to provide a structured overview of all included studies, data from all studies on the descriptors outlined in step (4) were combined into a table (Table 1). The first column presents a reference to the authors of the corresponding study. The column presenting the outcome 


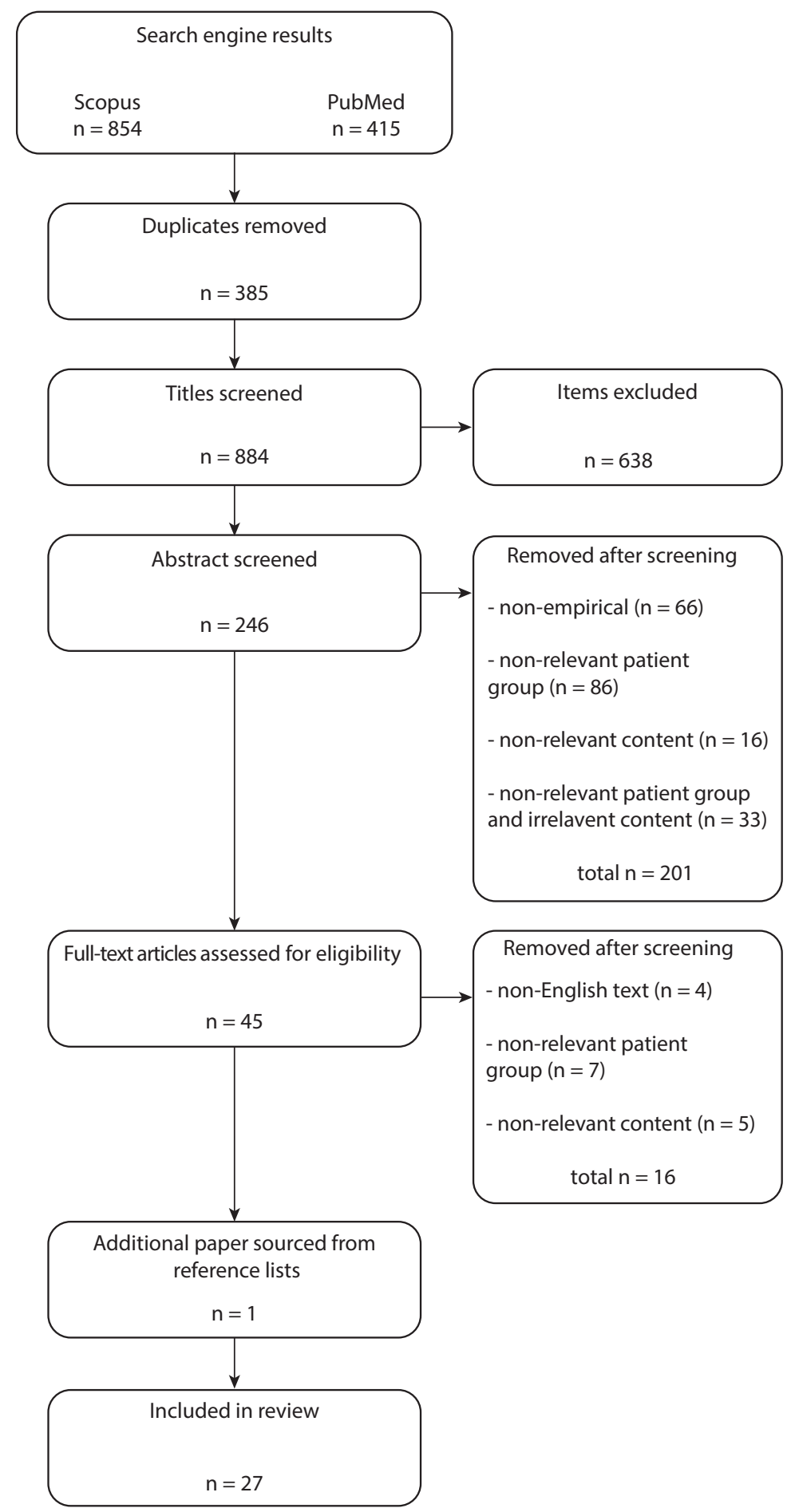

Figure 1. Flow of study selection for current review. 
variables for each study (study outcomes) indicates the finding of the ABI sample in comparison to the control groups, or according to defined stages of moral maturity.

\section{Results}

A total of 1269 articles were found in the initial search. After removing duplicate studies, screening titles and abstracts, 26 articles from the initial search met criteria for inclusion. One additional article was included through reference list checks; therefore, a total of 27 studies are included in this review. Figure 1 depicts a flow of study selection. Following identification of eligible studies, we identified the following four themes on what is known about moral cognition in ABI: (1) TBI versus non-TBI; (2) the influence of different approaches to measure moral cognition in ABI; (3) the role of age at onset of ABI on moral cognition and (4) the role of location of ABI on moral cognition. We will discuss the literature according to these themes.

\section{TBI versus non-TBI}

A first important notion is that ABI refers to all types of brain damage that occur after birth which can have either a traumatic or non-traumatic aetiology (Lezak, Howieson, Bigler \& Tranel, 2012). Important distinctions between these two forms of $\mathrm{ABI}$ are the cause and the type of brain injuries that commonly occur. TBI is characterised by an injury to the brain caused by a forceful impact or sudden jolt to the head (Anderson, Bigler \& Blatter, 1995; Levin \& Kraus, 1994; Meythaler, Peduzzi, Eleftheriou \& Novack, 2001). non-TBI are commonly the result of tumours, lesions, vascular malformations, anoxia or infections of the brain, often causing subarachnoid haemorrhages or other injuries (Teasell et al., 2007). Importantly, TBIs and non-TBIs do not lead to the same type of damage with respect to their location, typically, TBIs can cause widespread injury effects, whereas non-TBIs result in focal brain injuries. Moreover, since non-TBI has an internal cause, it cannot be ruled out that this by itself may have led to impairments in moral cognition. Among the nine studies in this review which included both types of ABI (i.e., TBI and non-TBI), one study (Ciaramelli, Braghittoni \& di Pellegrino, 2012) found the same results after excluding people with TBI from analysis. In this study, the aim was to assess moral cognition in people with focal ventromedial prefrontal cortex (vmPFC) damage; however, the authors could not rule out additional diffuse axonal injury in other regions of the brain in the TBI sub-group. We did not encounter any article that directly compared moral impairments between people with TBI and people with nonTBI. In this regard, for future studies, it is important to report the injury aetiology, since there may be differences in the injury being focal or widespread. Furthermore, if a mix of both TBI and nonTBIs make up one sample, it is advisable to re-run the analysis on the TBI and non-TBI group separately to ensure that moral impairments do not differ between the two types of ABI.

\section{The influence of different approaches to measure moral impairments in $A B I$}

Across the 27 selected studies, ten different approaches (see Table 1) have been used to index moral cognition in ABI. Five of these approaches, across 21 studies, assessed the individuals' ability to judge 'moral dilemmas'. Despite the common use of moral dilemmas, the ten approaches we found in our search still differed in various ways. Before discussing these different measurement approaches, it is important to distinguish between different outcome measures of moral cognition. In this review, moral cognition is used as an umbrella term for the concepts moral decision-making, model reasoning and moral judgement. Moral decision making, which can be a decision about how to behave in a real or hypothetical moral dilemma (i.e., lie or tell the truth). Moral reasoning in the current review refers to the individual's ability to give reasons for their decisions or judgements about social or moral behaviours (i.e., mature reasoning). Moral judgement refers to a 
judgement or evaluation about the moral acceptability of actions (e.g., judgement of moral character, estimating consequences or punishment allocation).

A key aspect that contributes to the differences in approaches used to measure moral cognition involves the content of the moral dilemmas. Moral dilemmas are focused on situations where there is a social problem that requires a response, this can include many a number of situations, such as, theft, property damage, dishonesty or harm to another person. The type of action that may or may not be carried out (i.e., the decision to be made) to resolve the social problem can vary in multiple ways, and this variation can affect how individuals respond. To better understand the importance of this issue, a distinction must be made between 'universal moral dilemmas' and 'sociomoral dilemmas'. Universal moral dilemmas are those which describe a typical moral dilemma (e.g., stealing medication for a sick family member). Whereas sociomoral dilemmas involve scenarios that are likely experienced in daily life (e.g., being pressured by peers to break school rules). According to our findings, the literature on moral cognition in people with ABI is largely dominated by the use of universal moral dilemmas. Namely, 16 out of the 21 studies using moral dilemmas made use of universal moral dilemmas and five used sociomoral dilemmas. The way moral cognition is mapped out is fundamental to how moral impairments are perceived in people with ABI. For example, modifying the content of the scenario in this way can alter the personal involvement of the participant (Dooley, Beauchamp \& Anderson, 2010). A large number of universal moral dilemmas used in the literature (i.e., the Heinz dilemma) are likely not realistic for the representative group. Therefore, although these scenarios may give insights into the processes involved in moral cognition, they provide limited insight into daily moral reasoning capabilities of the individuals; these skills are referred to as 'sociomoral skills' (Dooley et al., 2010; Haidt, 2001).

Aside from the overarching difference between universal moral dilemmas and sociomoral dilemmas, there are a number of other variations to the content of the dilemmas that alter how people with ABI respond. In nine of the studies where universal moral dilemmas were used, a distinction was made between 'impersonal' and 'personal' moral dilemmas. For example, in a scenario in which saving five lives requires one person to die, a personal moral dilemma is where the individual carrying out the action is directly involved in the production of harm (i.e., pushing a stranger off a bridge). An impersonal moral dilemma is where the individual carrying out the action is not directly involved in the production of harm (i.e., flipping a switch; Greene, Nystrom, Engell, Darley \& Cohen, 2004; Greene, Sommerville, Nystrom, Darley \& Cohen, 2001). Critically, whether the action in question is personal or impersonal has an impact on how individuals respond. Healthy individuals typically choose to permit the impersonal action, thereby saving multiple lives (i.e., utilitarian preference, which is defined as valuing actions that serve the aggregate welfare), whereas they typically choose to omit the personal action, thereby letting multiple people die (i.e., deontological preference, where the act is deemed right or wrong despite its consequences). Of the studies included in this review that assessed people with ABI on both personal and impersonal moral dilemmas, all except two (Craver et al., 2016; Ziaei, Togha, Rahimian \& Persson, 2019) found that people with ABI differ to healthy people in their responses to personal moral dilemmas; however, people with $\mathrm{ABI}$ and controls do not differ in their responses to impersonal moral dilemmas.

Similarly, the extremity of the scenario in universal moral dilemmas may impact how individuals respond. Kahane et al. (2012) found that in extreme dilemmas (e.g., where the action involves murder), healthy individuals' intuitive response is to omit the act, thereby not saving the most lives. On the other hand, in a less extreme scenario (e.g., where the action involves lying), healthy individuals intuitively choose to permit the act. One study made use of the distinction between extreme and less extreme dilemma's and presented them to people with ABI (Rowley, Rogish, Alexander \& Riggs, 2018). They found that the intuitiveness of the moral dilemma determined how people with $\mathrm{ABI}$ respond. The ABI group responded counterintuitively to both extreme and less extreme dilemmas (i.e., oppositely to healthy individuals). 
Aside from the content of moral dilemmas, a task characteristic which also relates to the individuals personal involvement in the dilemma includes the framing of the question in the dilemma. For example, after presenting individuals with a dilemma, there are a number of ways to ask the individual whether they should or should not endorse the action presented in the scenario. We observed that the phrasing of this question is not consistent across studies. Two examples are, 'What would you do?' versus 'What should you do?'. The former being a reflection of a personal standard, while the latter reflects awareness of a societal standard. This seemingly minor difference could alter the individual's personal involvement in the dilemma, through a switch to the firstperson perspective, and thus, affect their behavioural responses.

Another task characteristic which likely plays an important role in the assessment of moral cognition in people with $\mathrm{ABI}$ concerns the mode of task presentation. A number of studies presented ABI groups with lengthy written scenarios; meanwhile, other studies presented dilemmas using pictures, cartoons or virtual reality (see Table 1 for an overview of the different approaches used to assess moral cognition in $\mathrm{ABI}$ ). Impairments in other cognitive domains, such as attention or working memory, needed to perform the task, may influence peoples' responses. For example, the studies that assessed adolescents with ABI typically used picture scenarios and found less consistent differences between ABI groups and non-ABI groups (e.g., Beauchamp et al., 2013; Dooley et al., 2010). Though it is possible that an ABI occuring during adolescence results in less severe moral impairments, it cannot be ruled out that the task modality may play a role in the individual's ability to visualise the scenario. Given that no study has systematically compared different task modalities to examine how this effects moral cognition in people with ABI, this may be an opportunity for future research.

Lastly, studies in which the age of onset of ABI was the primary interest $(n=11)$ used moral dilemmas to assess individuals' moral maturity. Among these studies, the most important outcome variable was individuals' moral reasoning, that is, the justification of the decision made in the moral dilemma. Studies in which the focus of investigation was the location of the ABI (i.e., studies in people with focal ABI; $n=13$ ) typically assessed moral decision making, that is, the choice of which action to permit in the moral dilemma rather than moral reasoning. Consequently, different outcome measures (i.e., moral reasoning and moral decision making) were used to assess different $\mathrm{ABI}$ groups (i.e., age of onset $\mathrm{ABI}$ and focal ABI groups), making it almost impossible to compare moral cognition between these types of studies.

In sum, the content of moral dilemmas and the tools used to present these dilemmas play a crucial role in how people with ABI respond and therefore affect the interpretation of the extent of their impairments. Notably, since the extremity of the scenario impacts how people with ABI respond (Rowley et al., 2018), the common use of universal moral dilemmas, which often contain extreme and sometimes unrealistic scenario's, may not be an optimal measurement tool to assess moral cognition in people with ABI. For example, future research should focus on whether people with ABI respond differently to universal moral dilemmas versus sociomoral dilemmas. Additionally, for treatment and intervention purposes, further research must be carried out assessing the sociomoral skills between different age groups of people with ABI using age-appropriate, realistic scenarios.

\section{The role of age at onset of $A B I$ on moral cognition}

There are 11 studies that have investigated how the age of onset of an ABI affects moral cognition. All 11 studies assessed moral maturity using or referring to Kohlberg's model (Kohlberg, 1971, 1974), which includes three levels of moral maturity. In these studies, people are presented with a scenario in which there is a conflict between two moral imperatives and then asked to describe the protagonist's actions and their reasoning through a series of questions. For example, a scenario where a poor young man steals an expensive drug from a greedy pharmacist in order to save the life of his dying wife. The reasoning behind peoples' responses is indicative of their moral 
maturity. Three case studies and one group study inluded in this review tested moral reasoning in people who experienced an ABI at an early age (Anderson, Bechara, Damasio, Tranel \& Damasio, 1999; Grattan \& Eslinger, 1992; Price, Daffner, Stowe \& Mesulam, 1990). The people with the earliest occurring injuries, at 7 days, 4 years (Price et al., 1990), 3 months and 15 months (Anderson et al., 1999) all responded at the lowest level (Level 1) of moral maturity. This level is characteristic of moral reasoning of most healthy children under the age of 9 , even though all of these people were at adult age during testing. Children in which the ABI occurred later, at 7 years old in a case study (Grattan \& Eslinger, 1992) or under the age of 13 in one group study $(n=16$; Couper, Jacobs \& Anderson, 2002) were able to reason at a slightly higher level of moral maturity (Level 2). This level is typically achieved by most healthy children aged 10-13 years. At the time of testing, the 7-year-old case study was 33 years old; however, the children in the group study were still children/young adolescents. In a direct comparison to healthy children, Couper et al. (2002) found that children diagnosed with ABI responded with significantly lower levels of moral maturity with almost every person scoring lower than similarly aged healthy children. In sum, earlyonset $\mathrm{ABI}$ ( $<13$ years old) leads to impaired moral reasoning, despite being tested at a later age. These people, due to early brain damage, may have never acquired the socially relevant knowledge necessary for appropriate moral behaviour. From these four studies, a trend of increasing moral maturity in persons with later $\mathrm{ABI}$ onset is apparent. It is therefore possible that moral maturity could develop at a later stage before adulthood and that injuries occurring during adolescence may not result in such impairments.

Four studies included in this review investigated people who suffered ABI during adolescence (Beauchamp et al., 2013, 2019; Cook et al., 2013; Dooley et al., 2010). A newly developed task ('Somoral' and 'So-mature') was used in three studies (Dooley et al., 2010). This task was created specifically for understanding moral maturity in adolescents and used age-appropriate, daily moral reasoning scenarios, such as 'cheating in a game of pool', also known as sociomoral dilemmas. The So-moral component of the task measures the decision (e.g., 'Would you cheat?'). The So-mature component measures the reasoning of that decision. This second measure is used to indicate the individuals' moral maturity. Three studies compared the performance of adolescents with TBI to age-matched healthy controls on this task. In one study (Dooley et al., 2010), a group of adolescents $(n=25)$ with a history of (mostly mild) TBI scored within Level 2, which was not significantly different from age-matched controls and is indicative of their age according to the model. We related the scores reported in Dooley et al. (2010) to Kohlberg's model based on the cut-off scores given in Beauchamp et al. (2013). In Beauchamp et al. (2013), a group of adolescents $(n=25)$ with a mix of both moderate-severe and mild TBIs responded with different levels of moral maturity. Adolescents with moderate-severe TBIs responded at level 1, whereas the mild TBI group maintained an overall maturity level comparable to a healthy control group at level 2. These results suggest the severity of the TBI to be an important factor in determining moral maturity. The most recent study (Beauchamp et al., 2019) investigated a larger group of adolescents with TBIs $(n=43)$ and reported that the TBI group scored significantly lower on the moral maturity task compared to age-matched controls, regardless of the severity of the TBI. In this study, performance was scored differently to the other adolescent studies previously mentioned, and moral maturity could not be assessed according to Kohlberg's model. Two of the three studies (Beauchamp et al., 2013, 2019) also reported the scores on the decision-making component of the task. Interestingly, these results indicate that adolescents with ABI deviate less from healthy controls on the decision-making component compared to the reasoning component. The fourth study (Cook et al., 2013) used a novel virtual-reality task to assess adolescents with TBIs on two types of dilemmas: legal dilemmas (e.g., endorsing underage drinking) and sociomoral dilemmas (e.g., using a friend's answers to cheat on a test). The TBI group provided a comparable amount of short-term consequences as the control group, however, fewer long-term consequences in cases of sociomoral dilemmas. 
In sum, these studies together show mixed results as to whether there is an impairment in moral decision-making and moral reasoning when the ABI occurred during adolescence and whether the injury was severe or not. Together, these four adolescent studies present the possibility that adolescents with ABI may know what they need to do in sociomoral scenarios, however, cannot offer adequate reasoning for their decision. Moreover, all adolescent studies carried out testing while the people were still adolescents, compared to most early-onset studies that tested the people while in adulthood. This means that, in the case of impaired moral cognition, it is not clear whether adolescents with ABI remain at the same level of moral maturity through to adulthood. Moreover, in contrast to the early-onset studies, the exact age of onset of individuals in the sample was not reported, and this factor has not been considered in the analysis.

In two studies (Chiasson, Elkaim, Weil, Crevier \& Beauchamp, 2017; Taber-Thomas et al., 2014), the patient sample was made up of individuals where the onset occurred both before adolescence and during adolescence. Interestingly, both took the age of onset into account in their analysis and found that the earlier the injury occurred, the more moral maturity was hampered. This is inline with the early-onset and adolescent onset studies showing that the age of onset of the injury is crucial to the impairments in moral maturity.

Finally, we found two studies that investigated moral cognition in people who suffered ABI during adulthood. If impairments in moral cognition are solely caused by early acquired injuries, therefore hampering development, then there should not be an impairment when the injury occurs in adulthood. Evidence for this notion comes from a case study (Saver \& Damasio, $1991)$ and a group study ( $n=6$; Anderson et al., 1999) in which all of the people with ABI judged moral dilemmas at the either level 2 or level 3 of Kohlberg's model, thus suggesting preserved moral maturity. Together, these studies indicate that people with adult-onset ABI reach moral maturity stages comparable to healthy controls.

\section{The role of location of $A B I$ in moral cognition}

We encountered 13 articles where people with focal ABI were studied. Among these, nine studies assessed people with damage to the vmPFC, two studies assessed people with bilateral injuries to the hippocampus, one study included people with vmPFC and people with hippocampal lesions and one study assessed people with right frontopolar cortex lesions ( $\mathrm{rFPC}$ ). A further four studies were found which assessed people with widespread ABI.

Early neuroimaging studies have shown correlational evidence for the role of the vmPFC in moral cognition. Specifically during personal moral dilemmas, participants who showed vmPFC activity were more likely to condemn the personal act (i.e., to not push the stranger; Greene et al., 2001, 2004) and therefore show a deontological preference in these dilemmas. Five studies in this review directly tested the role of the vmPFC in moral decision-making (Ciaramelli, Muccioli, Làdavas \& Di Pellegrino, 2007; Koenigs et al., 2007; Moretto, Làdavas, Mattioli \& Di Pellegrino, 2010; Taber-Thomas et al., 2014; Thomas, Croft \& Tranel, 2011). In these studies, responses from healthy individuals and/or non-vmPFC brain-damaged controls were compared with the responses of people with vmPFC damage on moral dilemmas. Inline with the existing literature on moral decision-making, the control groups always showed a deontological preference (i.e., choosing not to endorse the act and not maximize the aggregate welfare) in personal moral dilemmas (i.e., when the act involves directly harming someone). Across all five studies, however, people with vmPFC damage consistently showed the opposite preference to the control groups in personal moral dilemmas, indicating these violations to be more acceptable and opting to maximize the aggregate welfare (i.e., utilitarian preference).

According to Koenigs et al. (2007), the responses of the ABI group differed to controls predominantly in dilemmas where healthy individuals responded slower and with lower agreement (i.e., 'high-conflict' dilemmas). Moretto et al. (2010) showed that a lack of sympathetic arousal (measured 
with skin-conductance responses) in people with vmPFC damage in response to moral dilemmas may contribute to these atypical moral responses. This abnormal response persisted in people with ABI, even when the directness and perspective of the dilemmas were altered (Thomas et al., 2011). For example, where the person on the sidetrack is your daughter (directness), or when the act is carried out by them, or someone else (perspective). Lastly, further support for abnormal moral preferences, particularly in early-onset cases, comes from a comparison study of the people with adult-onset ABI from Koenigs et al. (2007) with a group of early/adolescent-onset vmPFC-damaged people (Taber-Thomas et al., 2014). Dividing dilemmas into 'self-serving' and 'non-self-serving' scenarios, results showed that the people with developmental-onset ABI displayed the same abnormal preferences in personal moral dilemmas (i.e., utilitarian preference), however, that they also endorsed significantly more 'self-serving' dilemmas compared to the adult-onset group, demonstrating abnormally egocentric moral judgements, which, according to Kohlberg's model, falls inline with lower levels of moral reasoning.

In sum, damage to the vmPFC results in a utilitarian preferences by placing more weight on the outcome of the scenario than the action itself in moral dilemmas. However, according to these studies, this preference only deviates from healthy controls under certain conditions, such as when the dilemmas are deemed 'personal dilemmas'. Contrary to this claim, however, Rowley et al. (2018) raises the possibility that moral dilemmas are characterised as either 'intuitively utilitarian' or 'intuitively deontological', having found that people with widespread ABIs responded with an overall counterintuitive bias. This study shows that the responses of people with ABI may largely depend on the nature of the scenario (i.e., being extreme or less extreme) and highlights the importance of the content of the moral dilemmas as a determining task characteristic.

Similar moral decision-making preferences were observed in two studies that assessed people with widespread ABI, where they showed a utilitarian preference on personal moral dilemmas (Martins, Faisca, Esteves, Muresan \& Reis, 2012; Njomboro, Humphreys \& Deb, 2014). Njomboro et al. (2014) also examined people who suffered widespread ABI while experiencing apathy symptoms, measured via caregivers' responses to the Apathy Evaluation Scale (Marin, Biedrzycki \& Firinciogullari, 1991). Scores above 41 on this scale indicated the presence of apathy in these people, with this group showing stronger utilitarian preferences in response to personal moral dilemmas compared to people with $\mathrm{ABI}$ with no apathy. It is possible that the people in these studies suffered damage to the vmPFC as well as other regions; however, the exact location of injuries is not reported.

A further four studies in people with vmPFC damage assessed different aspects of moral cognition compared to the previously mentioned studies and therefore they are discussed separately. Two of these studies investigated whether individuals with damage to the vmPFC process harmful intent differently to healthy individuals (Ciaramelli et al., 2012; Young et al., 2010). When we attempt to understand and evaluate others actions, we may question, for example, whether they intended to cause harm. To disentangle the contribution of intentions (e.g., actions carried out in order to reach a goal) and outcomes (e.g., the consequences of the action) to moral judgement in people with vmPFC damage, both studies manipulated the intention of the moral agent and the outcomes of that action. The comparison control groups for these studies were also healthy individuals and/or non-vmPFC brain-damaged controls. Inline with the expectation that vmPFC damaged people place more weight on the outcome of the scenario than the action itself (i.e., utilitarian vs. deontological), both studies found that individuals with vmPFC damage judged a failed attempt to harm as more permissible (Ciaramelli et al., 2012; Young et al., 2010) and accidental harm as less permissible (Ciaramelli et al., 2012) than controls. This means that people with vmPFC damage do not place weight on the intention when making a moral judgement of others' actions that are potentially harmful. An individual, therefore, who accidentally harms someone may be more harshly condemned by vmPFC damaged people than an individual who attempts to harm someone but fails at doing so. Relatedly, Asp and colleagues (2019) sought to understand the 
role of the vmPFC in 'third-party punishment', which is a behavioural component involving punishment allocation. Third-party punishment is when a participant observes moral violations and can punish the violating person (i.e., allocating lesser punishment for accidental, non-violent crimes or greater punishment for intended, violent crimes). The fact that third-party punishment is altruistic (i.e., meaning that it is costly to the punisher and does not result in direct benefits) suggests that motivation for justice or fairness plays a big role, closely linking it with morality. In accordance with the previous findings (Ciaramelli et al., 2012; Young et al., 2010), people with vmPFC damage assigned more lenient punishments to criminals that committed violent crimes, whereas punishments allocated to criminals that committed non-violent crimes were equal to healthy controls (Asp et al., 2019). This study provides evidence for deficits in the moral act of third-party punishment among people with vmPFC ABI.

Vascello and colleagues (2018) found that people with widespread ABIs more easily endorsed moral violations than 'socio-conventional transgressions', which involve a violation of convention without the involvement of harm, injustice or rights violations; those that do include these refer to moral violations (Vascello et al., 2018). Lastly, a study investigated how people with vmPFC damage differ in their spontaneous, unintentional judgements about moral actions, termed, implicit moral judgement (Cameron, Reber, Spring \& Tranel, 2018). In this study, participants made rapid moral judgements to different types of words (morally wrong words, e.g., genocide, non-moral negative words, e.g., rejection and, neutral words, e.g., agreement). A distractor word was presented for $100 \mathrm{~ms}$ after a target word. The participants responded about whether the target word was morally wrong. Through measuring the number of errors, the authors clarified three possible processes driving judgement throughout the task: intentional judgement, unintentional judgement or response bias. People with vmPFC damage exhibited reduced unintentional judgement as well as lower intentional judgements overall. These findings did not generalize to negative or neutral words, suggesting this was not a domain-general affective deficit. In sum, the study suggests a dual deficit in not only intentional moral judgement (Ciaramelli et al., 2007; Koenigs et al., 2007; Martins et al., 2012; Moretto et al., 2010; Njomboro et al., 2014; Taber-Thomas et al., 2014; Thomas et al., 2011; Vascello et al., 2018) but also unintentional moral judgements in individuals with focal vmPFC ABIs (Cameron et al., 2018).

The hippocampus is a brain structure critical for supporting cognitive functions such as declarative memory (Tulving \& Markowitsch, 1998). Declarative memory may contribute to judgements on moral dilemmas. Namely, scene construction, a critical aspect of moral reasoning, relies on our ability to recollect past experiences and integrate relevant information and is known to rely on the hippocampus (Addis, Wong \& Schacter, 2007). The ability to visualise scenes may be compromised in people with hippocampal lesions; therefore, moral reasoning may also be altered. From our literature search, we encountered two studies that assessed moral decision-making in people with hippocampal damage.

Contrary to individuals with vmPFC lesions as shown in other studies, who tend to show a preference for utilitarian choices in (high-conflict) personal moral dilemmas, one study (McCormick, Rosenthal, Miller \& Maguire, 2016) found that people with hippocampal lesions more often chose to omit the act (i.e., deontological preference) in high-conflict personal moral dilemmas. Interestingly, the hippocampal ABI groups indicated via subjective reports that their decisions were heavily influenced by an initial adverse emotional response to the task (e.g., having to kill somebody), rather than overcoming this response and visualising the bigger picture of saving the most lives. This inability to visualise the scene may stem from declarative memory deficits present in these people. High levels of sympathetic arousal (measured using skin-conductance responses) in people with hippocampal lesions during decision-making corroborated the subjective reports that these people experienced greater emotional responses to moral dilemmas in comparison to controls. Contrary to these results, Craver et al. (2016) suggest that people with hippocampal lesions do not differ to healthy individuals in their moral judgements, finding that both groups exhibited similar patterns in moral 
preferences, with a deontological preference in personal moral dilemmas, however, not an exaggerated deontological bias as was found by McCormick et al. (2016). Both studies (Craver et al., 2016; McCormick et al., 2016) used written text as the mode of stimulus presentation. Crucially, if the use of text-based stimuli contributes to the observed exaggerated deontological responses in individuals with hippocampal damage (McCormick et al., 2016), by impaired ability to visualise the scene, then providing visual stimuli (i.e., pictures, videos), instead of text-based stimuli, could alter the moral decisions of these individuals.

Lastly, one study (Croft et al., 2010) assessed 'moral-updating', which is the process of updating character judgements of others, based on observing them engage in social and moral behaviours, in both people with hippocampal lesions and people with vmPFC lesions. Individuals with vmPFC damage demonstrated reduced moral updating, this means that despite learning about morally bad behaviour from a person, these individuals would still believe the person to be moral. People with hippocampal lesions, however, showed the opposite change, generating exaggerated moral updating, meaning they would more likely change their judgements about a person's moral character in response to observing morally relevant behaviours. These findings support the notion that a possible consequence of the declarative memory deficits present in individuals with hippocampal lesions (i.e., not being able to visualise the whole scene in their head) may result in overvaluing emotional input, thereby leading to increased moral updating. This final study demonstrates the different preferences observed in people with vmPFC and hippocampal ABI. Low rates of moral updating as observed in people with vmPFC damage falls inline with these individuals showing exaggerated utilitarian preferences, whereby the action itself is not heavily judged, but rather the outcome (Ciaramelli et al., 2007; 2012, Koenigs et al., 2007; Moretto et al., 2010; Taber-Thomas et al., 2014; Thomas et al., 2011; Young et al., 2010). Relative to this, increased moral updating falls in line with individuals with hippocampal lesions showing exaggerated deontological preferences, whereby the moral action is more harshly judged (McCormick et al., 2016).

Besides the vmPFC and hippocampus, the rPFC has been considered to play a role in processes that contribute to moral judgements. A recent study (Ziaei et al., 2019) explored the causal role of the rFPC in moral judgements by comparing responses to personal and impersonal moral dilemmas (Greene et al., 2001) in people with rFPC damage and healthy controls. Emotions were induced prior to making these judgements by showing participants neutral or emotional pictures. The two groups did not differ in utilitarian preferences nor in reaction time for personal or impersonal moral dilemmas. Furthermore, both groups were similarly affected by the emotion induction, providing more utilitarian responses to personal and impersonal moral dilemmas following negative pictures. These results give proof of the fact that neural processes contributing to normal moral judgement do not crucially depend on the rFPC, since moral judgements were intact in individuals with focal rFPC damage (Ziaei et al., 2019).

\section{Discussion}

With this scoping review, we aimed to unravel the extent to which individuals with ABI suffer deficits in moral reasoning and moral decision-making. These studies together provide insight into the neural underpinnings of moral cognition. They also give insight into the complexity of measuring this illusive concept. Given the high prevalence of ABI and its impact on society (Menon \& Bryant, 2019), understanding impairments due to ABI is timely and important. People with ABI often show impairments in moral cognition, particularly when the injury occurred at a young age, and future studies should investigate whether improvements in moral cognition can be made post-injury. We also found that the literature on moral cognition in people with $\mathrm{ABI}$ has largely been dominated by the use of universal moral dilemmas; however, dilemmas that focus on daily moral reasoning capabilities might provide a more valid approach to measure 
moral reasoning capabilities in these individuals. We conclude that there is a complex interplay between the age the injury was acquired, the location of the injury and the measurement approach used to index moral cognition, all of which determine how the moral impairments in ABI patients are manifested.

The age of onset of the injury plays an important role in the development of moral cognition. According to the studies we found, moral cognition is thought to transition through stages which have been found to coincide with age (Colby \& Kohlberg, 1987; Kohlberg, 1971, 1974). Early-onset brain damage results in severe developmental deficits, with individuals demonstrating a moral maturity level far below their age-appropriate stage (Anderson et al., 1999; Grattan \& Eslinger, 1992; Price et al., 1990). It is worth noting, however, that all early-onset ABI cases report damage to the frontal lobes. Therefore, it still remains unclear whether early-onset damage to other regions result in similar moral deficits or whether moral reasoning and moral decision-making remains intact. In contrast to early-onset ABI, adult-onset ABI cases show far less deficits in the severity of moral maturity (Anderson et al., 1999; Saver \& Damasio, 1991; Taber-Thomas et al., 2014). Together, these studies show that early damage results in moral deficits compared to damage acquired during adulthood, indicating the possibility of a sensitive period of moral development during childhood.

Studies conducted in people with adolescent-onset ABI depict a less clear picture of how moral maturity is affected after injury. Importantly, the task most often used in adolescent studies had an outcome variable for moral decision-making (So-moral task) and moral reasoning (So-mature task). The comparison of these responses provides insight into the difference between knowing what the individual should do and having the capacity to provide adequate reasoning for the decision (Beauchamp et al., 2013). Compared to healthy controls, individuals with adolescent-onset ABI show a similar response patterns with regard to moral decision-making, but differ in their moral reasoning (Beauchamp et al., 2013, 2019; Cook et al., 2013). No study to date, however, has tested people with adolescent-onset $\mathrm{ABI}$ at an adult age. It is unclear, therefore, whether moral cognition can still further develop through adolescence. Given the importance of both the age of onset of ABI and the age of testing in moral cognition, we would like to recommend that all future studies report these two variables, even if they do not take them into account in their statistical analysis.

An important conceptual difference between the way that moral cognition has been studied in adolescent ABI groups in comparison to other ABI groups (i.e., early-onset and adult-onset) is through the use of sociomoral dilemmas in the place of universal moral dilemmas. These two types of dilemmas likely tap into different processes, with sociomoral dilemmas increasing the personal and emotional involvement of the individual. An important avenue for future research would be to conceptualise moral dilemmas that are likely to be experienced in daily life by the representative age group. Moreover, since there are no training or intervention studies that have aimed to improve moral reasoning in people with ABI that occurred during development, ageappropriate sociomoral dilemmas may provide the tool to do so.

Studies in which the focus was on the location of the injury show that depending where the ABI occurs in the brain, moral cognition can be impaired in different ways. We found that most of the studies investigating individuals with focal $\mathrm{ABI}$ had damage to the vmPFC and a few studies included people with focal hippocampal damage. Damage to the vmPFC disrupts the social emotional responses found in healthy participants, and thus, result in abnormally utilitarian preferences (Ciaramelli et al., 2007; Koenigs et al., 2007; Martins et al., 2012; Moretto et al., 2010; Thomas et al., 2011). This means that even in the case of permitting an extreme act, such as murder, people with vmPFC damage would more likely choose to save the maximum number of people and prevent the most amount of suffering. People with hippocampal lesions, however, tend to show the reverse preference, favouring deontological responses. These people would consider whether the action (e.g., murder) is right or wrong, rather than placing weight on the consequences of that action. Interestingly, people with vmPFC and hippocampal lesions both show moral 
cognition impairments, but with reverse preferences from each other. This could be explained by the known role of the vmPFC in integration and regulation of emotional responses (Bechara, Damasio, Tranel \& Anderson, 1998) and the role of the hippocampus in imagination and future thinking (Maguire \& Hassabis, 2011). Remarkably, we did not encounter studies with focal lesions in other regions of 'the moral brain' (Moll et al., 2005) such as the dlPFC or the amygdala, and it is possible that lesions in such regions may also lead to moral deficits, but this remains to be investigated.

Moral cognition in ABI has been assessed using several different approaches; consequently, some interpretations may deviate due to differences in assessment approaches. First, the earliest tasks that measured moral reasoning included the Standard Issue Moral Judgement and the Sociomoral Reflection Measure. Typically, in these tasks, individuals are presented with lengthy written scenarios, which they are instructed to read and reflect upon. Impairments on this task could be a consequence from impairments in other cognitive functions, such as attention or working memory, needed to perform the task. It is possible that a task presented in a different modality (i.e., via pictures, story boards or cartoons), which have mostly been used to assess moral cognition in adolescence (Beauchamp et al., 2013, 2019; Chiasson et al., 2017; Dooley et al., 2010), may lead to a different outcome in early-onset ABI too. Thus, not only the age of onset differs between these two groups of studies but also the assessment approach used to index moral maturity. A comparison between findings should, therefore, be taken with caution since any differences could alternatively be explained by different task modalities. Second, the content of the moral dilemmas also impacts the way people with ABI respond. For example, six studies found that people with vmPFC damage (Ciaramelli et al., 2007; Koenigs et al., 2007; Moretto et al., 2010; Thomas et al., 2011) and people with general ABI (Martins et al., 2012; Njomboro et al., 2014) show a utilitarian preference in personal moral dilemmas. However, Rowley et al. (2018) show that when the extremity of the scenario is taken into account, the preferences of people with general ABI show a different response pattern. Third, the framing of the question in moral dilemmas may also contribute significantly to how people with ABI respond. For example, a moral dilemma where participants are asked 'What would you do?' vs. 'What should you do?' could alter the individuals personal involvement in the scenario, where the latter taps into awareness of a social standard rather than a personal standard. Future research may, therefore, aim to standardize the way moral cognition is assessed in individuals with ABI to improve our understanding of moral impairments when injuries occur at different ages and in different brain regions.

Financial support. There was no funding for this research project.

Conflicts of interest. The authors declare no conflict of interest.

\section{References}

Addis, D. R., Wong, A. T., \& Schacter, D. L. (2007). Remembering the past and imagining the future: Common and distinct neural substrates during event construction and elaboration. Neuropsychologia, 45(7), 1363-1377. doi: 10.1016/j. neuropsychologia.2006.10.016

Anderson, C. V., Bigler, E. D., \& Blatter, D. D. (1995). Frontal lobe lesions, diffuse damage, and neuropsychological functioning in traumatic brain-injured patients. Journal of Clinical and Experimental Neuropsychology, 17(6), 900-908. doi: 10. 1080/01688639508402438

Anderson, S. W., Bechara, A., Damasio, H., Tranel, D., \& Damasio, A. R. (1999). Impairment of social and moral behavior related to early damage in human prefrontal cortex. Nature Neuroscience, 2(11), 1032-1037. doi: 10.1038/14833

Anderson, V., Beauchamp, M. H., Yeates, K. O., Crossley, L., Ryan, N., Hearps, S. J., \& Catroppa, C. (2017). Social competence at two years after childhood traumatic brain injury. Journal of Neurotrauma, 34(14), 2261-2271. doi: 10.1089/neu. 2016.4692

Asp, E. W., Gullickson, J. T., Warner, K. A., Koscik, T. R., Denburg, N. L., \& Tranel, D. (2019). Soft on crime: Patients with ventromedial prefrontal cortex damage allocate reduced third-party punishment to violent criminals. Cortex, 119, 33-45. doi: 10.1016/j.cortex.2019.03.024 
Beauchamp, M. H., Dooley, J. J., \& Anderson, V. (2013). A preliminary investigation of moral reasoning and empathy after traumatic brain injury in adolescents. Brain Injury, 27(7-8), 896-902. doi: 10.3109/02699052.2013.775486

Beauchamp, M. H., Vera-Estay, E., Morasse, F., Anderson, V., \& Dooley, J. (2019). Moral reasoning and decision-making in adolescents who sustain traumatic brain injury. Brain injury, 33(1), 32-39.

Bechara, A., Damasio, H., Tranel, D., \& Anderson, S. W. (1998). Dissociation of working memory from decision making within the human prefrontal cortex. Journal of Neuroscience, 18(1), 428-437. doi: 10.1523/jneurosci.18-01-00428.1998

Cameron, C. D., Reber, J., Spring, V. L., \& Tranel, D. (2018). Damage to the ventromedial prefrontal cortex is associated with impairments in both spontaneous and deliberative moral judgments. Neuropsychologia, 111, 261-268. doi: 10.1016/j. neuropsychologia.2018.01.038

Chiasson, V., Elkaim, L., Weil, A. G., Crevier, L., \& Beauchamp, M. H. (2017). Moral reasoning in children with focal brain insults to frontotemporal regions. Brain Impairment, 18(1), 102-116. doi: 10.1017/BrImp.2016.33

Ciaramelli, E., Braghittoni, D., \& di Pellegrino, G. (2012). It is the outcome that counts! Damage to the ventromedial prefrontal cortex disrupts the integration of outcome and belief information for moral judgment. Journal of the International Neuropsychological Society, 18(6), 962. doi: 10.1017/S1355617712000690

Ciaramelli, E., Muccioli, M., Làdavas, E., \& Di Pellegrino, G. (2007). Selective deficit in personal moral judgment following damage to ventromedial prefrontal cortex. Social Cognitive and Affective Neuroscience, 2(2), 84-92. doi: 10.1093/scan/ nsm001

Cicerone, K. D., \& Tanenbaum, L. N. (1997). Disturbance of social cognition after traumatic orbitofrontal brain injury. Archives of Clinical Neuropsychology, 12(2), 173-188. doi: 10.1016/S0887-6177(96)00022-4

Colby, A., \& Kohlberg, L. (1987). The measurement of moral judgment: Volume 1. In The measurement of moral judgment: Volume 1.

Colquhoun, H. L., Levac, D., O'Brien, K. K., Straus, S., Tricco, A. C., Perrier, L., . . Moher, D. (2014). Scoping reviews: time for clarity in definition, methods, and reporting. Journal of clinical epidemiology, 67(12), 1291-1294.

Cook, L. G., Hanten, G., Orsten, K. D., Chapman, S. B., Li, X., Wilde, E. A., . . Levin, H. S. (2013). Effects of moderate to severe traumatic brain injury on anticipating consequences of actions in adolescents: A preliminary study. Journal of the International Neuropsychological Society, 19(5), 508. doi: 10.1017/S1355617712001452

Couper, E., Jacobs, R., \& Anderson, V. (2002). Adaptive behaviour and moral reasoning in children with frontal lobe lesions. Brain Impairment, 3(2), 105. doi: 10.1375/brim.3.2.105

Craver, C. F., Keven, N., Kwan, D., Kurczek, J., Duff, M. C., \& Rosenbaum, R. S. (2016). Moral judgment in episodic amnesia. Hippocampus, 26(8), 975-979. doi: 10.1002/hipo.22593

Croft, K. E., Duff, M. C., Kovach, C. K., Anderson, S. W., Adolphs, R., \& Tranel, D. (2010). Detestable or marvelous? Neuroanatomical correlates of character judgments. Neuropsychologia, 48(6), 1789-1801. doi: 10.1016/j. neuropsychologia.2010.03.001

Dooley, J. J., Beauchamp, M., \& Anderson, V. A. (2010). The measurement of sociomoral reasoning in adolescents with traumatic brain injury: A pilot investigation. Brain Impairment, 11(2), 152-161. doi: 10.1375/brim.11.2.152

Gibbs, J. C., Basinger, K. S., \& Fuller, D. (1992). Moral Maturity: Measuring the development of sociomoral reflection. Hillsdale, New Jersey: Lawrence Erlbaum.

Grattan, L. M., \& Eslinger, P. J. (1992). Long-term psychological consequences of childhood frontal lobe lesion in patient DT. Brain and Cognition, 20(1), 185-195. doi: 10.1016/0278-2626(92)90068-W

Greene, J. D., Nystrom, L. E., Engell, A. D., Darley, J. M., \& Cohen, J. D. (2004). The neural bases of cognitive conflict and control in moral judgment. Neuron, 44(2), 389-400. doi: 10.1016/j.neuron.2004.09.027

Greene, J. D., Sommerville, R. B., Nystrom, L. E., Darley, J. M., \& Cohen, J. D. (2001). An fMRI investigation of emotional engagement in moral judgment. Science, 293(5537), 2105-2108. doi: 10.1126/science.1062872

Haidt, J. (2001). The emotional dog and its rational tail: A social intuitionist approach to moral judgment. Psychological Review, 108(4), 814. doi: 10.1037/0033-295X.108.4.814

Hanten, G., Cook, L., Orsten, K., Chapman, S. B., Li, X., Wilde, E. A., . . Levin, H. S. (2011). Effects of traumatic brain injury on a virtual reality social problem solving task and relations to cortical thickness in adolescence. Neuropsychologia, 49(3), 486-497.

Kahane, G., Wiech, K., Shackel, N., Farias, M., Savulescu, J., \& Tracey, I. (2012). The neural basis of intuitive and counterintuitive moral judgment. Social Cognitive and Affective Neuroscience, 7(4), 393-402. doi: 10.1093/scan/nsr005

Koenigs, M., Young, L., Adolphs, R., Tranel, D., Cushman, F., Hauser, M., \& Damasio, A. (2007). Damage to the prefrontal cortex increases utilitarian moral judgements. Nature, 446(7138), 908-911. doi: 10.1038/nature05631

Kohlberg, L. (1971). Stages of moral development. Moral Education.

Kohlberg, L. (1974). The claim to moral adequacy of a highest stage of moral judgment. The Journal of Philosophy, 70(18), 630-646. doi: 10.2307/2025030

Lalonde, G., Bernier, A., Beaudoin, C., Gravel, J., \& Beauchamp, M. H. (2018). Investigating social functioning after early mild TBI: The quality of parent-child interactions. Journal of Neuropsychology, 12(1), 1-22. doi: 10.1111/jnp.12104

Levin, H., \& Kraus, M. F. (1994). The frontal lobes and traumatic brain injury. The Journal of Neuropsychiatry and Clinical Neurosciences. doi: 10.1176/jnp.6.4.443 
Lezak, M. D., Howieson, D. B., Bigler, E. D., \& Tranel, D. (2012). Neuropsychological assessment: OUP USA.

Maguire, E. A., \& Hassabis, D. (2011). Role of the hippocampus in imagination and future thinking. Proceedings of the National Academy of Sciences, 108(11), E39-E39. doi: 10.1073/pnas.1018876108

Marin, R. S., Biedrzycki, R. C., \& Firinciogullari, S. (1991). Reliability and validity of the Apathy Evaluation Scale. Psychiatry Research, 38(2), 143-162. doi: 10.1016/0165-1781(91)90040-V

Martins, A., Faisca, L., Esteves, F., Muresan, A., \& Reis, A. (2012). Atypical moral judgements following traumatic brain injury. Judgment and Decision Making, 7(4), 478-487.

McCormick, C., Rosenthal, C. R., Miller, T. D., \& Maguire, E. A. (2016). Hippocampal damage increases deontological responses during moral decision making. Journal of Neuroscience, 36(48), 12157-12167. doi: 10.1523/JNEUROSCI. 0707-16.2016

Menon, D. K., \& Bryant, C. (2019). Time for change in acquired brain injury. The Lancet Neurology, 18(1), 28. doi: 10.1016/ S1474-4422(18)30463-0

Meythaler, J. M., Peduzzi, J. D., Eleftheriou, E., \& Novack, T. A. (2001). Current concepts: Diffuse axonal injury-associated traumatic brain injury. Archives of Physical Medicine and Rehabilitation, 82(10), 1461-1471. doi: 10.1053/apmr.2001.25137

Moll, J., Zahn, R., de Oliveira-Souza, R., Krueger, F., \& Grafman, J. (2005). The neural basis of human moral cognition. Nature Reviews Neuroscience, 6(10), 799-809. doi: 10.1038/nrn1768

Moretto, G., Làdavas, E., Mattioli, F., \& Di Pellegrino, G. (2010). A psychophysiological investigation of moral judgment after ventromedial prefrontal damage. Journal of Cognitive Neuroscience, 22(8), 1888-1899. doi: 10.1162/jocn.2009.21367

Njomboro, P., Humphreys, G. W., \& Deb, S. (2014). Exploring social cognition in patients with apathy following acquired brain damage. BMC Neurology, 14(1), 18. doi: 10.1186/1471-2377-14-18

Palmer, E. J., \& Hollin, C. R. (1999). Social competence and sociomoral reasoning in young offenders. Applied Cognitive Psychology: The Official Journal of the Society for Applied Research in Memory and Cognition, 13(1), 79-87. doi: 10. 1002/(SICI)1099-0720(199902)13:1 <79:AID-ACP613>3.0.CO;2-Q

Price, B. H., Daffner, K. R., Stowe, R. M., \& Mesulam, M. M. (1990). The comportmental learning disabilities of early frontal lobe damage. Brain, 113(5), 1383-1393. doi: 10.1093/brain/113.5.1383

Rowley, D. A., Rogish, M., Alexander, T., \& Riggs, K. J. (2018). Counter-intuitive moral judgement following traumatic brain injury. Journal of Neuropsychology, 12(2), 200-215. doi: 10.1111/jnp.12117

Saver, J. L., \& Damasio, A. R. (1991). Preserved access and processing of social knowledge in a patient with acquired sociopathy due to ventromedial frontal damage. Neuropsychologia, 29(12), 1241-1249. doi: 10.1016/0028-3932(91)90037-9

Schofield, P. W., Mason, R., Nelson, P. K., Kenny, D., \& Butler, T. (2019). Traumatic brain injury is highly associated with self-reported childhood trauma within a juvenile offender cohort. Brain Injury, 33(4), 412-418. doi: 10.1080/02699052. 2018.1552020

Sirois, K., Tousignant, B., Boucher, N., Achim, A. M., Beauchamp, M. H., Bedell, G., ... Jackson, P. L. (2017). The contribution of social cognition in predicting social participation following moderate and severe TBI in youth. Neuropsychological Rehabilitation. doi: 10.1080/09602011.2017.1413987

Stams, G. J., Brugman, D., Deković, M., Van Rosmalen, L., Van Der Laan, P., \& Gibbs, J. C. (2006). The moral judgment of juvenile delinquents: A meta-analysis. Journal of Abnormal Child Psychology, 34(5), 692-708. doi: 10.1007/s10802-0069056-5

Taber-Thomas, B. C., Asp, E. W., Koenigs, M., Sutterer, M., Anderson, S. W., \& Tranel, D. (2014). Arrested development: Early prefrontal lesions impair the maturation of moral judgement. Brain, 137(4), 1254-1261. doi: 10.1093/brain/awt377

Teasell, R., Bayona, N., Marshall, S., Cullen, N., Bayley, M., Chundamala, J., . . \& Tu, L. (2007). A systematic review of the rehabilitation of moderate to severe acquired brain injuries. Brain Injury, 21(2), 107-112. doi: 10.1080/02699050701201524

Thomas, B. C., Croft, K. E., \& Tranel, D. (2011). Harming kin to save strangers: Further evidence for abnormally utilitarian moral judgments after ventromedial prefrontal damage. Journal of Cognitive Neuroscience, 23(9), 2186-2196. doi: 10.1162/ jocn.2010.21591

Tricco, A. C., Lillie, E., Zarin, W., O'Brien, K. K., Colquhoun, H., Levac, D., . . Straus, S. E. (2018). PRISMA extension for scoping reviews (PRISMA-ScR): Checklist and explanation. Annals of Internal Medicine, 169(7), 467-473. doi: 10.7326/ M18-0850

Tulving, E., \& Markowitsch, H. J. (1998). Episodic and declarative memory: Role of the hippocampus. Hippocampus, 8(3), 198-204. doi: 10.1002/(SICI)1098-1063(1998)8:3<198:AID-HIPO2>3.0.CO;2-G

Turiel, E. (1983). The development of social knowledge: Morality and convention. Cambridge, UK: Cambridge University Press.

Turkstra, L. S., Norman, R. S., Mutlu, B., \& Duff, M. C. (2018). Impaired theory of mind in adults with traumatic brain injury: A replication and extension of findings. Neuropsychologia, 111, 117-122. doi: 10.1016/j.neuropsychologia.2018.01.016

Vascello, M. G., Marchetti, M., Scaltritti, M., Altoè, G., Spada, M. S., Molinero, G., \& Manfrinati, A. (2018). Are moral and socio-conventional knowledge impaired in severe traumatic brain injury?. Archives of Clinical Neuropsychology, 33(5), 583595. doi: 10.1093/arclin/acx099

Young, L., Bechara, A., Tranel, D., Damasio, H., Hauser, M., \& Damasio, A. (2010). Damage to ventromedial prefrontal cortex impairs judgment of harmful intent. Neuron, 65(6), 845-851. doi: 10.1016/j.neuron.2010.03.003 
Young, L., Cushman, F., Hauser, M., \& Saxe, R. (2007). The neural basis of the interaction between theory of mind and moral judgment. Proceedings of the National Academy of Sciences, 104(20), 8235-8240.

Young, L., \& Dungan, J. (2012). Where in the brain is morality? Everywhere and maybe nowhere. Social Neuroscience, 7(1), 1-10. doi: 10.1080/17470919.2011.569146

Ziaei, M., Togha, M., Rahimian, E., \& Persson, J. (2019). The causal role of right frontopolar cortex in moral judgment, negative emotion induction, and executive control. Basic and Clinical Neuroscience, 10(1), 37. doi: 10.32598/bcn.9.10.225

Cite this article: Lloyd B, Montoya ER, de Voogd LD, and Oudman E. Unravelling moral cognition in acquired brain injury: a scoping review. Brain Impairment. https://doi.org/10.1017/BrImp.2021.7 